\title{
Press Coverage of Environmental Pollution In The Niger Delta Region of Nigeria. A Content Analysis of the Guardian, Vanguard, Daily Sun and Thisday Newspapers
}

\author{
Dr. Nnanyelugo Okoro ${ }^{1}$, Godwin O. Nnaji ${ }^{2}$ \\ 1 senior Lecturer and Head, Department Of Mass Communication, University Of Nigeria, Nsukka, Nigeria.
}

\begin{abstract}
Over the years, the Niger Delta region of Nigeria has always received negative media publicity due to its restive youth who, under several fronts, have been campaigning against alleged pillage of the region by the oil companies as well as "neglect" of the region by the federal government of Nigeria. The region has also been agitating against the "massive destruction" of their farmlands, water resources and the general ecology of the region, occasioned by the activities of oil companies in the region, resulting in environmental degradation and pollution. This study is a content analysis of four mainline newspapers in Nigeria: The Guardian, Vanguard, Daily Sun and Thisday. It was aimed at ascertaining whether the Nigerian press covers environmental pollution and the extent of the coverage, in addition to forms of environmental pollution in the Niger Delta, as covered by the Nigerian press. Using random sampling, 90 issues of each of the papers were selected (from 1092 issues) within the study period - September 2010 to May 2011. The study found that environmental pollution in the region by the press received low coverage. The study also revealed that environmental issues are largely confined to the inside pages of the newspapers.
\end{abstract}

Key words: coverage, degradation environment, pollution, waste disposal

\section{Introduction}

One of the greatest problems facing the Niger Delta region in Nigeria is that of environmental pollution which causes great damages to the earth. Environmental pollution takes place when the environment cannot process and neutralize harmful by-products of human activities in due course without any structural or functional damage to its system.

Pollution occurs when the natural environment is unable to decompose the generated elements and on the other hand, when man fails to decompose these pollutants artificially. This has negative impacts on crucial environmental services such as provision of clean water and arable land without which life on earth as we know it would be difficult.

Environmental pollution is a problem both in developed and developing countries. Factors such as population growth and urbanization invariably place greater demands on the environment and stretch the use of natural resources to the maximum. Such overuse of natural resources often results in nature's degradation.

The environment is said to be polluted when there is substantial alteration in form and function of the components of the physical environment which in turn produces harmful effects on human beings. The key word here is "substantial", which is used to show that no component of the physical environment can be considered to be polluted until it has been altered in form or function in such a way that it can immediately or potentially harm human beings directly or indirectly.

In Niger Delta region of Nigeria, one of the threatening environmental problems prevalent in the area is environmental pollution caused by oil exploration and related activities. As an oil producing region, oil spillage is one of the most outstanding causes of water and land or soil pollution while air pollution is mostly caused by gas flaring and industrial effluents. The direct impact of oil exploration in the region has been felt by everyone living in the area. Some of these issues include ecological degradation, environmental pollution, associated human rights abuses, high inflation and loss of livelihood. The popular argument is that it could only be fair if these groups of people are appropriately compensated.

Niger Delta, according to Ashong and Aniefiok (2007:195) [1], is of two classifications, namely: physiographic (core) Niger Delta and oil producing Niger Delta. The core Niger Delta includes states like Akwa-Ibom, Bayelsa, Cross River, Delta, Edo, Ondo and Rivers. The Niger Delta, as currently defined by government, comprises Abia, Akwa-Ibom, Bayelsa, Cross River, Delta, Edo, Imo, Ondo and Rivers states with a total of 185 local government areas and a combined population of over 28 million persons.

The mangrove forests of the Niger Delta are important ecological resource as they provide essential ecosystem including soil stability, medicines, healthy fisheries, wood for fuel and shelter, tannins and dyes, and critical wildlife habitats. Oil spills contribute to degradation and destruction of the mangrove forests. 
Endangered species such as Delta elephant, the white monkey, the river hippopotamus, and crocodiles are increasingly threatened by the activities of the oil companies.

The issue of man's insensitivity to his environment was considered so important by the United Nation General Assembly that in 1984, it set up a body known as the World Commission on Environment and Development (WCED) to formulate a global agenda for a positive change in this area. Back home in Africa, the first African Ministerial Conference on the Environment (AMCEN) held in Cairo, Egypt came up with what they called the Cairo Programme for African Co-operation, which among other things emphasized the need to combat environmental degradation or pollution (Onumonu, 1986)

In Nigeria, Federal Environmental Protection Agency (FEPA) was established by decree No. 58 of 1998 to ensure the protection of the environment from the abuse of the oil companies. This led to the setting up of similar agencies in the states of the federation. The Agency (FEPA) became a full fledge Ministry- Federal Ministry of Environment in 1999 saddled with the responsibility of protecting Nigerian environment and conserving her resources as well. Other institutions set up by the government include: Department of Petroleum Resources charged with the responsibility of ensuring compliance to various regulations on oil (Adeyanju, 2004) [2].

These bodies are charged with maintaining environmental friendliness through monitoring and coordinating human activities at the international, national and local levels. They are to sensitize and persuade individuals, groups and organizations on dangers of less environmental friendly attitudes and to regulate man's activities on the environment as well.

However, the problem still remains how the activities of these bodies, agencies and ministry are reported upon or gets to the publics to achieve the intended results. Thus, this study was aimed at finding out if Nigerian press covers environmental pollution in the Niger Delta.

The press as the watchdog of the society is expected to draw attention of the public, the government and organizations to environmental problems around them; one of which is environmental pollution. It is against this backdrop that the study seeks to investigate press coverage of environmental pollution in the Niger Delta region of Nigeria using content analytical research method. The study spans from September 1, 2010- May 31 2011.

\section{Problem}

Years of insensitivity to environmental issues or near complete lack of attention to environmental concerns have turned the Niger Delta into one of the most endangered ecosystems in the country. Various forms of ecological activities go on in the region. Prominent among them is oil exploration. This has led to springing up of industries whose activities also generate wastes which are not properly managed and result in environmental pollution.

Since there is a great link between awareness or knowledge and action, socially responsible media in their reportage can make issues to be seen as important at a given time in a given society by placing emphasis on such issues. This could be through frequency of reports, prominence given to the reports and analysis of the issues at stake. Thus, this study sought to ascertain the position of the Nigeria press in this regard.

The focus of this study was to:

\section{Study Focus}

1. Find out if Nigerian press covers environmental pollution in Niger Delta region.

2. Ascertain the extent of coverage given to environmental pollution in the Niger Delta region.

3. Find out the status of environmental pollution projection by the Nigeria press

4. Find out the prevalent environmental pollution forms in the Niger Delta, as reflected by the Nigeria press.

\section{Research Questions}

The following research questions were formulated to guide the study;

1. Does Nigerian press cover environmental pollution in the Niger Delta?

2. What is the extent of coverage given to environmental pollution in the Niger Delta?

3. What is the status of environmental pollution projection in the Nigerian press?

4. What are the prevalent environmental pollution forms in the Niger Delta as reflected by the Nigerian press?

\section{Incidences of Environmental Degradation}

In a recent United Nations Environment Programme (UNEP, 2011) analysis on Ogoniland, UNEP scientists found an eight centimeter layer of refined oil floating on the groundwater which serves wells in the area. This was reportedly linked to an oil spill which occurred more than six years ago (Ajaero 2011: 20) [3].

In Niger Delta, farmlands, mangroves, fishes, drinking waters are gone due to oil spills leading to degradation of the ecosystem. Soil on farmlands are turned cakes of crude oil, fishes are gone due to polluted 
water, drinking waters are contaminated, crops are stained, witted and die due to crude oil, fumes from gas flaring visit the people with breathing difficulties.

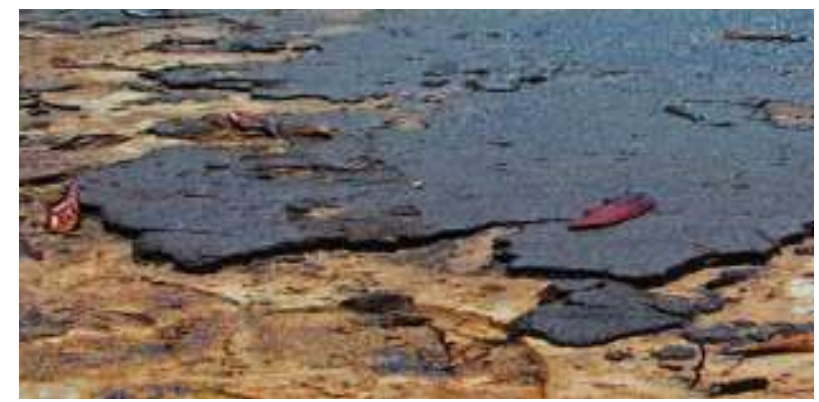

figure 1: soil caked into a crust of dried crude oil. Source: UNEP (2011) Ogoniland environmental analysis

Presenting the UNEP Environmental Assessment of Ogoniland in August 4, 2011, Ibranhim Thiaw, UNEP Director, Division for environmental policy, noted that it took more than 14 months to do the report during which period 200 locations were visited, 122- kilometer pipeline rights of way surveyed, 5000 medical reports examined; and 23,000 people were interacted with at local community meetings. According to UNEP, given the dynamic nature of oil pollution and extent of contamination, failure to begin addressing urgent public health concerns and commencing a clean up will only exacerbate and unnecessarily prolong the Ogoni people's suffering (Ajaero Supra).

According to UNEP reports full environmental restoration of Ogoniland will take an estimated time of 25 to 30 years and would need N150 billion. This will be possible through a combination of modern technology to clean up contaminated land and water ways, backed up by practical action at the regulatory, operational and monitoring levels, the report suggested (Ikuomola 2011 August 5:8) [4].

Table 1: Number of oil spill and the volume in barrels in Nigeria between 1976 and 1983.

\begin{tabular}{|c|c|c|}
\hline YEAR & NO. OF SPILLS & VOLUME IN BARRELS \\
\hline 1976 & 128 & 20,023 \\
\hline 1977 & 104 & 31,144 \\
\hline 1978 & 154 & 97,250 \\
\hline 1979 & 157 & 603,405 \\
\hline 1980 & 241 & 558,053 \\
\hline 1981 & 233 & 22,840 \\
\hline 1982 & 213 & 33,612 \\
\hline 1983 & 130 & 32,467 \\
\hline Total & 1,364 & $1,425,794$ \\
\hline
\end{tabular}

Source: Nwankwo and Ifeadi in Obot et al 2010: 217

\section{Well Blowouts}

According to United Nations Environment Programme (UNEP) "blowouts" is oil industry terminology for a situation in which control of oil well is lost during drilling or operation. More frequent during drilling, blowouts lead to the release of hydrocarbons (crude oil, produced water and associated gas) into the environment. Often, such mixture will catch fire and burn until such times the well is brought back under control. Blowouts could be caused by pressure, corrosion and illegal tapping leading to oil spills and fires. Such fire or spill can take months before it could be brought under control. Bellow is a picture of a well blowout.

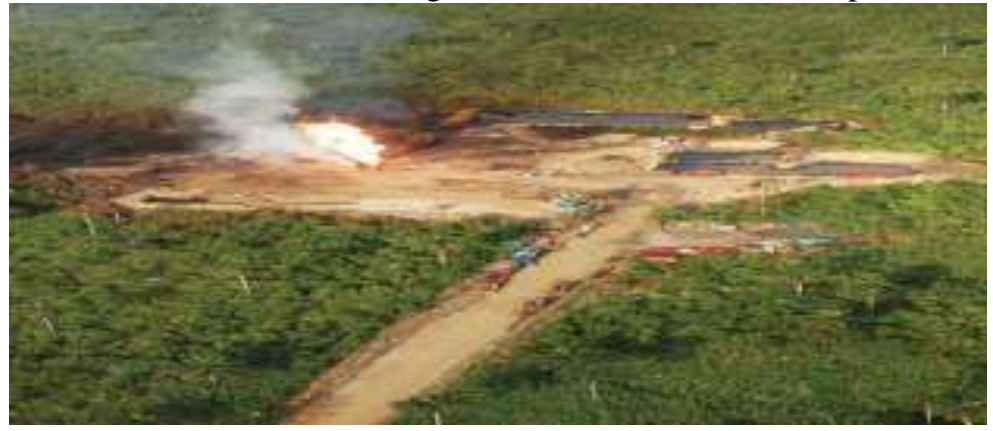

figure 2: An oil well on fire (Yorla 13, Khana LGA of Rivers State) Source: UNEP (2011) Ogoniland environmental analysis. 
In 1975, Shell BP leaked 600,000 barrels of crude oil into the seas of Forcados terminal and in 1980; 200,000 barrels of crude oil were spilled as a result of Texaco oil well blow out. Between 1997 and 1998, more than 900,000 barrels crude oil were spilled as a result of rupturing in Escravos terminal of Delta State (Ogboi, E in Kperegbeyi et al 2005:119) [5].

Recently, on January 16, 2012, there was another blow out at Chevron's Funiwa Field, 10 kilometres offshore. This has become the latest in the series of environmental disasters in the Niger Delta due to oil and gas related operation. This will bring about steaming temperatures, acidification of the waters and air miles around the natural gas rig, thus causing a great damage of marine life. Communities affected by the blow out are Koluama I and II, Sangana, Foropa, Bisangbene, Ezetu, and others, all in Bayelsa State.

6.1 Equipment failure: This is another oil spillage factor which could result from poorly maintained equipment used in oil exploration and transportation. In May and December 2001, pressure surge valve of Exxon Mobil and SPDC opened due to equipment failure causing Qua Iboe terminal Tank Farm spill and Umudike II spill in Ohaji Egbema Local Government of Imo State.

\subsection{Abandoned oil facility}

An abandoned oil facility in the Niger Delta is another cause of environmental pollution in the area. In Ogoniland for example, some containers are left lying around since SPDC were forced out of the area some years ago. Where such containers are not empty, there are no indications of the contents. Tampering with such facility may lead to fire outbreak. From the environmental point of view, UNEP notes that corrosion of such metallic objects leads to ground contamination by heavy metals

\subsection{Artisanal Refining}

Artisanal refining means local and crude way of refining petroleum products. This involves the use of metal drums to boil crude oil whose fumes are collected in tanks through pipes welded together. This is common in the Niger Delta region where distilleries are heated on open fire throwing dark plumes of smokes into the air and increasing the risk of fire outbreak. Also, soil where such practice took place will suffer contamination from hydrocarbons. Bellow is photograph showing air pollution resulting from artisanal refining and the resultant effect on the land.

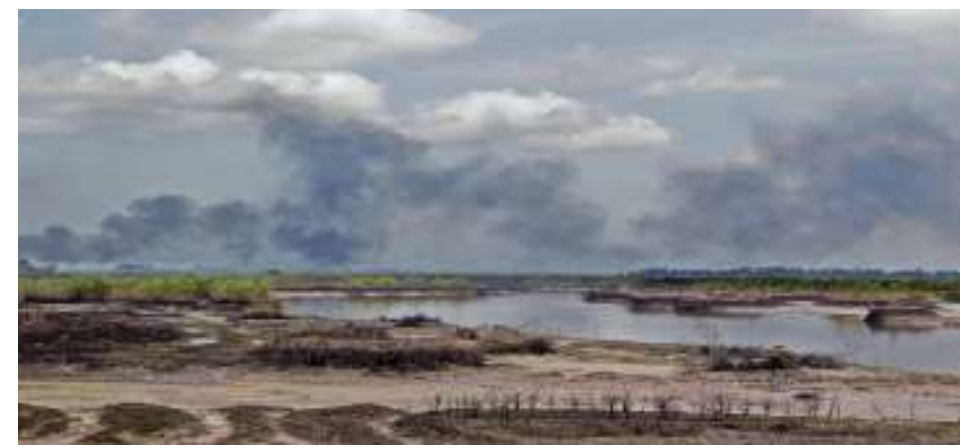

Figure 3: Smoke from artisanal refining, a common sight in Ogoniland Source: UNEP (2011) Ogoniland environmental analysis.

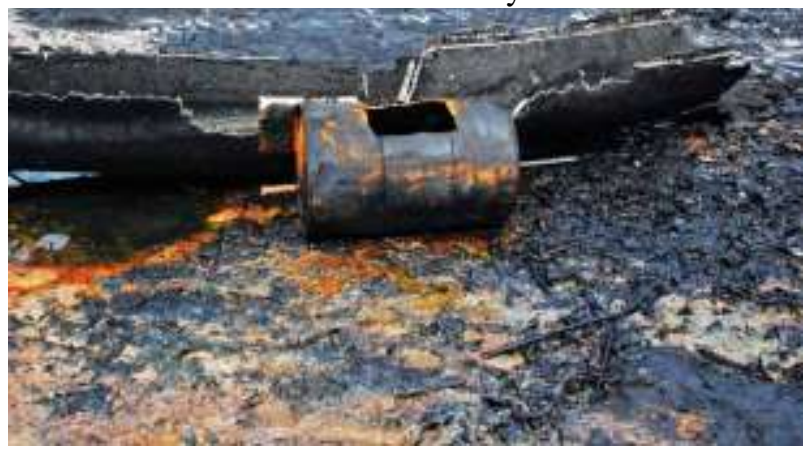

Fgure 4: total environmental devastation. Source: UNEP (2011) Ogoniland environmental analysis. 
Press Coverage Of Environmental Pollution In The Niger Delta Region Of Nigeria. A Content

\begin{tabular}{|c|c|c|c|c|}
\hline YEAR & LOCATION & $\begin{array}{l}\text { QUANTITY } \\
\text { SPILLED }\end{array}$ & $\begin{array}{l}\text { CAUSES OF } \\
\text { SPILLAGE }\end{array}$ & $\begin{array}{c}\text { EFFECT ON } \\
\text { ENVIRONMENT }\end{array}$ \\
\hline 1979 & Forcados terminal & 570,000 & $\begin{array}{l}\text { Terminal had } \\
\text { accidental rupture of } \\
\text { the bottom plate }\end{array}$ & $\begin{array}{l}\text { Fishing activities } \\
\text { inhabited Mangrove } \\
\text { destroyed }\end{array}$ \\
\hline 1980 & $\begin{array}{l}\text { Funiwa oil well } \\
\text { blow out }\end{array}$ & 421,000 & Oil well blow out & $\begin{array}{l}\text { Destruction to fish, crab, } \\
\text { etc. socio-economic } \\
\text { activities affected }\end{array}$ \\
\hline 1980 & Oyakama & 30,000 & & $\begin{array}{l}\text { Over } 25 \text { hectares of land } \\
\text { destroyed }\end{array}$ \\
\hline 1981 & Abudu pipeline & 5,240 & $\begin{array}{l}\text { Pay loader destroyed } \\
\text { oil pipeline }\end{array}$ & $\begin{array}{l}\text { Damage to agric } \\
\text { products, water, soil and } \\
\text { marine life }\end{array}$ \\
\hline 1983 & Oshika & 10,000 & Pipeline rupture & $\begin{array}{l}\text { Fish destroyed, water } \\
\text { contaminated }\end{array}$ \\
\hline 1986 & $\begin{array}{l}\text { Funiwa oil blow } \\
\text { out }\end{array}$ & 200,000 & Oil well blow out & $\begin{array}{l}\text { About } 350 \text { hectares of } \\
\text { mangrove destroyed; } \\
\text { fish killed. }\end{array}$ \\
\hline 1994 & $\begin{array}{l}\text { Agoda/ Brass oil } \\
\text { pipeline }\end{array}$ & & Pipeline corrosion & $\begin{array}{l}\text { Over } 10 \text { sq. km. of } \\
\text { farmland destroyed. } \\
\text { Ponds, lakes and } \\
\text { streams contaminated }\end{array}$ \\
\hline 1998 & Idoho (Mobil) & 401,000 & Offshore discharge & $\begin{array}{l}\text { Over } 10 \text { sq. km. of } \\
\text { farmland destroyed. } \\
\text { Pond, lakes and streams } \\
\text { contaminated }\end{array}$ \\
\hline 2003 & $\begin{array}{l}\text { Kwale oil well } \\
\text { explosion }\end{array}$ & & $\begin{array}{l}\text { Maintenance of } \\
\text { facilities suspected }\end{array}$ & \\
\hline 2003 & $\begin{array}{l}\text { Kalabilema oil } \\
\text { spill / explosion }\end{array}$ & & $\begin{array}{l}\text { Oil spilled and } \\
\text { explosion followed } \\
\text { causes not yet } \\
\text { ascertained }\end{array}$ & About 5 lives were lost. \\
\hline
\end{tabular}

Source: Adeyanju, J. A. 2004: $218-219$

\subsection{Improper Industrial Waste Disposal}

Industrial wastes are disposed in the region without regard to human life and safety as well as its effects on the environment. An example is a waste disposed of in several hundred big bags of 1 cubic metre reinforcement plastic bags which amounted to 1,100-1,500 cubic metres of oil mixed with gray clay containing small rock fragments with seeping from the bags, forming puddles in the ground and leaching into the soil (UNEP 2011:103) [6].

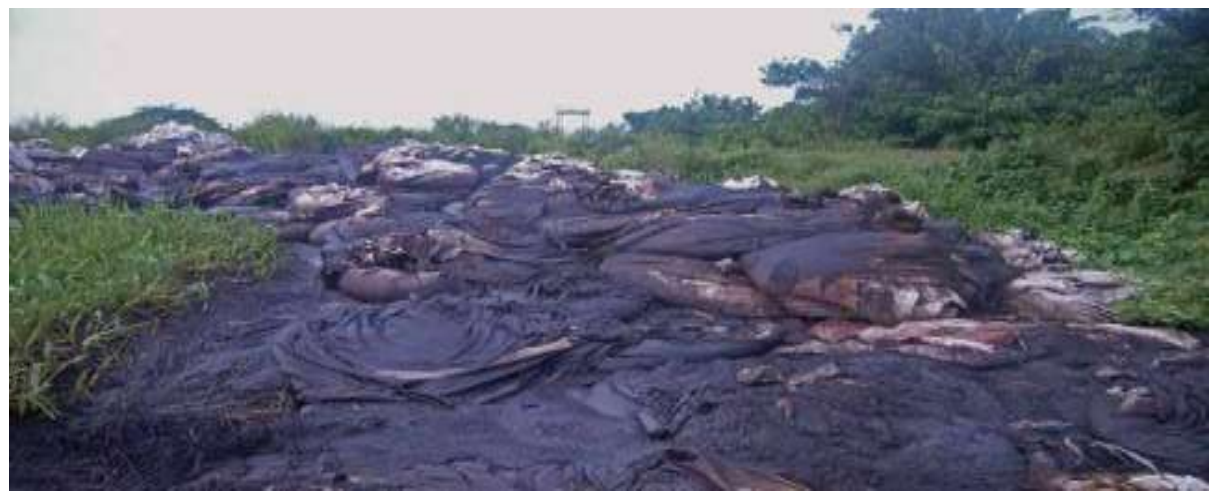

Figure 5: Tipping of oil waste in Okan Oyaa, Eleme LGA Source: UNEP (2011) Ogoniland environmental analysis.

In 1999, for instance, tragedy befell the citizens of Erovie, a community in the Niger Detla who were poisoned by toxic waste from Shell Oil's Operations. Local residents experienced health problems after Shell Oil Company injected liters of waste into an abandoned oil well in Erovie. Many who consumed crops or drank 
water from swamps in the area complained of vomiting, dizziness, stomach ache and cough. (Ofehe: 2010) [7]. This graphic example is a case of what environmental pollution can result to.

6.5 Sabotage: This is a deliberate nefarious human activity on oil pipelines either for the purpose of making quick money or willfully making oil companies suffer loss. According Ikporukpo (1986) cited in Ekpo (2010: 168) [8], sabotage as an oil spillage factor accounts for $3 \%$ of the total oil spills world wide and about $33 \%$ of oil spills in Nigeria. For instance, in August 2001, several kilometers of the Trans Niger pipeline were excavated and cut in sizable lengths for onward transportation to buyers. This act spilled oil at B-Dere and K-Dere communities in Gokana Local Government Area of Rivers State.

Also in August 2001, 3/4 inch plug belonging to Exxon Mobil were removed which led to Qua Iboe terminal spill in Mkpanak which affected vegetations, farmlands, and buildings in the vicinity of the spill point (Ugochukwu, Onyema in Nwosu and Uffoh 2005: 134) [9].

Table 3: Major oil spills in the Niger Delta in 2001

\begin{tabular}{|c|l|l|l|l|l|}
\hline & SPILL INCIDENT & DATE & $\begin{array}{l}\text { COMPANY } \\
\text { INVOLVED }\end{array}$ & $\begin{array}{l}\text { CAUSES OF } \\
\text { SPILL }\end{array}$ & $\begin{array}{l}\text { HABITAT } \\
\text { IMPACTED }\end{array}$ \\
\hline 1 & $\begin{array}{l}\text { Qua Iboe terminal } \\
\text { Tank farm spillage }\end{array}$ & $16 / 5 / 2001$ & Exxon Mobil & $\begin{array}{l}\text { Pressure Surge; } \\
\text { valve Opened due }\end{array}$ & $\begin{array}{l}2 \frac{1}{2} \text { km stretch of } \\
\text { coastline impacted } \\
\text { by crude oil. }\end{array}$ \\
\hline 2 & $\begin{array}{l}\text { Oil spillage and } \\
\text { explosion at Umudike } \\
\text { II in Ohaji Egbema } \\
\text { Local Government } \\
\text { Area }\end{array}$ & $3 / 11 / 2001$ & SPDC & Equipment failure & $\begin{array}{l}\text { Farmland, homes } \\
\text { and vegetation }\end{array}$ \\
\hline 3 & $\begin{array}{l}\text { Fire outbreak and } \\
\text { pipeline vandalization } \\
\text { at B-Dere } \\
\text { Communities in } \\
\text { Gokana Local } \\
\text { Government Area }\end{array}$ & $25 / 8 / 2001$ & SPDC & $\begin{array}{l}\text { Sabotage: several } \\
\text { kms of the trans } \\
\text { Niger pipeline were } \\
\text { excavated and cut in } \\
\text { sizeable lengths for } \\
\text { onward } \\
\text { transportation to } \\
\text { buyers }\end{array}$ & $\begin{array}{l}\begin{array}{l}\text { Swampy Basins and } \\
\text { vegetation which } \\
\text { fonsts secondary }\end{array} \\
\text { forest farmland }\end{array}$ \\
\hline 4 & $\begin{array}{l}\text { Qua Iboe terminal spill } \\
\text { in Mkpanak }\end{array}$ & $8 / 8 / 2001$ & Exxon Mobil & $\begin{array}{l}\text { Sabotage: suspected } \\
3 / 4 \text { inch plug was } \\
\text { removed }\end{array}$ & $\begin{array}{l}\text { Grassland and some } \\
\text { buildings in the } \\
\text { vicinity of the spill } \\
\text { point }\end{array}$ \\
\hline
\end{tabular}

Source: Ugochukwu, Onyema in Nwosu and Uffoh 2005: 134

\subsection{Gas Flaring:}

Gas flaring brings about ecosystem heat stress and acid rain. Acid rain in turn induces the destruction of fresh water fishes and forests (Adeyanju 2004) [10]. In another report, Oladejo (1998[11]) in Adeyanju (2004) [12] noted that constant gas flaring in the oil producing areas of Niger Delta contributes significantly to the atmospheric level of carbon dioxide, which is a major component of green house gases that causes global warming phenomenon.

\section{Environmental Consequences of Petroleum Hydrocarbons}

United Nations Environment Programme in a recent Environmental Assessment of Ogoniland noted the followings about petroleum hydrocarbons and its consequences on the environment. In their report, hydrocarbon is naturally occurring compound comprising hydrogen and carbon. Hydrocarbons can be as simple as methane (CH4), but many are highly complex molecules and can occur as gases, liquids or solids. The molecules can have the shape of chains, branching chains, rings, or other structures. Petroleum is a complex mixture of hydrocarbons. The most common hydrocarbons are natural gas, oil and coal (UNEP 2011:239) [13]. Hydrocarbons are formed by the decay of organic substances trapped within sedimentary rocks. High temperatures and pressure convert the trapped matter into hydrocarbons. Liquid hydrocarbon found in nature is also referred to as crude oil (UNEP 2011:36) [14].

Looking at the environmental consequences of hydrocarbons, it is important to remember that 'hydrocarbons' is an umbrella term used for hundreds of different organic compounds. Secondly, hydrocarbons can cause environmental consequences due to their chemical properties or physical properties. The economic significance of hydrocarbons as the primary source of fuel and its versatile application in downstream industries are obvious, the product may also have major environmental consequences. Oil exploration, production and processing represent prime sources of exposure to petroleum hydrocarbons. But there are other possible sources, 
such as vehicle and generator emissions, burning of vegetation and trash, food processing and use of cooking fuels.

\subsection{Impacts of Hydrocarbons on Soil}

When hydrocarbons come into contact with the soil, they alter its physical and chemical properties. The degree of alteration depends on the soil type, the specific composition of the hydrocarbon spilled and the quantity spilled. In the least damaging scenario, such as a small spill of a volatile hydrocarbon onto dry sand, the hydrocarbons evaporate fast, causing no chemical or physical damage to the soil. In other situations, for example a spill of heavy crude oil onto clay soil, the chemicals can remain within the soil for decades, altering its permeability, causing toxicity and lowering or destroying the quality of the soil.

In such circumstances, the soil itself will become a source of pollution. Contaminated soil can affect the health of organisms through direct contact or via ingestion or inhalation of soil contaminants which have been vaporized. Soil also acts as a reservoir of residual pollution, releasing contaminants into groundwater or air over extended period of time, often after the original source of pollution has been removed.

\subsection{Impacts Hydrocarbons on Water}

The impact of hydrocarbon on water is dependent on the specific chemical composition and physical characteristics of the hydrocarbon involved and the degree of concentration or dilution. Hydrocarbons can cause both physical and chemical effects in water; even very small quantities of hydrocarbon can prevent oxygen transfer in the water column, thus affecting aquatic life-support systems. The presence of mere traces of a highly toxic hydrocarbon, such as benzene, may render water unfit for human consumption.

\subsection{Impacts of Hydrocarbons on Vegetation}

Impacts of hydrocarbon on vegetation depend on a range of factors, from the type and quantity of the chemical(s) involved, to the life-cycle development stage of the plants concerned, and the means through which the plants came into contact with the hydrocarbon. Different vegetation types also have varying sensitivity to hydrocarbons.

\subsection{Impacts on Aquatic and Terrestrial Wildlife}

Oil spills can affect wildlife, both aquatic and terrestrial, in many ways. The severity of damage will depend on the type(s) of hydrocarbon involved, the quantity spilled, the temperature at the time of the incident, and the season. Dissolved or emulsified oil in the water column can contaminate plankton, algae, fish eggs and invertebrate larvae (UNEP 2011:38) [15].

Physical contact with oil destroys the insulation properties of fur and feathers, causing various effects in birds and fur-bearing mammals. Heavily oiled birds can also lose their ability to fly, as well as their buoyancy, causing drowning. In efforts to clean themselves, birds often ingest oil, which may have lethal or sublethal impacts through, for example, liver and kidney damage.

\subsection{Impacts on People}

People might be exposed to petroleum-contaminated surface water or groundwater when used for bathing, washing, cooking and drinking. People of all ages can also be exposed to petroleum that evaporates into the air. Members of fishing communities risk exposure to petroleum if they drink, bathe or collect shellfish in contaminated water, or if they come into contact with or accidentally ingest contaminated sediment while engaged in any of these activities (UNEP 2011:39) [16].

For instance, a research conducted by the faculty of Pharmacy University of Lagos, found a chemical, benzo (a) pyrene, an alternate polynuclear hydrocarbon, in water samples taken from 18 different sites in the Niger Delta. The chemical according to the researchers, in a report published in the Nigeria Quarterly Journal of Medicine, vol 14, July-December 2004, threatens the lives of the people through exposure to the skin, lungs, breasts and abdominal cancer

Dermal exposure can lead to skin redness, oedema, dermatitis, rashes and blisters; inhalation exposure can lead to red, watery and itchy eyes, coughing, throat irritation, shortness of breath, headache and confusion; and ingestion of hydrocarbons can lead to nausea and diarrhoea.

\section{Literature Review}

A study by B.A Chokor (1985) [16] on three Nigerian newspapers: The Daily Time, New Nigeria and Concord reported that environmental issues covered by these three newspapers constituted 7\%, $8 \%$ and 5\% respectively while over $18 \%$ and $24 \%$ of the published stories in Daily Times and The Concord was devoted to economic issues. This is a clear indication that Nigeria media and media practitioners then pay little or no attention to environmental issues and problems. 
Also, K. S. Olugbemi (1992) [17] in another content analysis on Newspaper coverage of environmental issues and problems in Nigeria noted that the newspapers he studied gave inadequate coverage to environmental issues and problems in Nigeria. Similarly, M .N. Akpa (1995) [18] content analyzed four national daily newspapers in the topic, Newspaper coverage of urban waste and environmental sanitation in Nigeria and discovered inadequate coverage of environmental issues in the country.

In the 1990s, Ikechukwu Nwosu (1997) [19] studied two government newspapers (New Nigerian and Daily Times) and two privately - owned Nigerian newspapers ( The Champion and The Guardian) using content analysis research method. The study revealed among other things, that the media in Nigeria did not only quantitatively undercover environmental issues and problems, but gave low quality coverage of the little they published

Also, Nathaniel Anokwute (1999) [20] studied the same newspapers analyzed by Nwosu; New Nigerian, Daily Times, Champion and Guardian; and concluded that the newspapers studied did not give adequate coverage and analysis of environmental pollution, issues and problems.

In another research work, Ashong and Udoudo (2007) [21] in a survey of media coverage of environmental pollution as a factor in agricultural development in the Niger Delta noted that Nigerians need more information on the environmental situation in the Niger Delta. On the contrary, Onyilo (2011) [22] in her assessment of press reports on environmental issues in Nigeria studied 4 Nigerian newspapers; The Guardian, Punch, Champion and New Nigerian and found out that the press carried favourable and indepth reports on environment. However, the report was silent on the extent of coverage.

Furthermore, Ashong and Udoudo (2007) [23] in their work, media coverage of environmental pollution as a factor in agricultural development in the Niger Delta interviewed 21 journalists on the barriers militating against effective communication on environmental pollution in the Niger Delta and discovered that lack of editorial policy, non- enforcement of environmental protection standards by the government, in accessibility to information, poor terrain and transport problem, lack of media commitment, and Government interference are the factors that hamper effective communication on environmental pollution in the Niger Delta. From the foregoing, there are clear indications that a lot of factors are responsible for the poor coverage of environmental issues by the press in the country. These in no small measure have affected the perception of ordinary citizens on what constitutes environmental risk and how to achieve environmental sustainability.

Man has influenced his physical environment so much through his activities, most of which are carried out in ignorance of their consequences. Hence, there is the need for environmental information through enlightenment programmes in form of jingles, debate, symposia and seminars to make man realize that those activities engaged by him to produce livelihood and to improve his life must be done with utmost caution (Busari, 2005) [24]. This would ensure meeting the need of the present generation without compromising that of the future generation.

Besides, public awareness on environmental issues will intimate man on the effects of some industrial operations on his health and the physical environment, enlighten him on various environmental laws and regulations that are available in our society and inspire a greater sense of respect for the environment. Bearing in mind that problems of environmental pollution are traced to man's activities that accumulate in bits and consequently altering his environment negatively, environmental information and awareness campaign will enlighten the people to understand the consequence of their action to avert any further degradation of the environment (Akporido, 1997) [25] and develop a citizenry that is aware of and concerned with the total environment (Moemeka, 1983 in Akporido, 2005) [26]. Also, this will bring about much reportage on environmental issues in the Nigeria press.

According to Odufuwa, (2005: 236) [27] environmental education should be able to create awareness about environmental problems, motivate people to devoid from extravagance, conserve resources and protect environment; facilitate understanding and co-operation among people toward sustainable environmental issues; conserve indigenous knowledge, traditions and culture friendly to the environment. Such will inspire widespread public participation on all fronts and enable all, from the grass roots, through the relevant agencies to the leaders to understand the stakes, the urgent need for action and the necessary steps that must be taken towards sustainable national environmental protection. (Onyelucheya, 2003: 144) [28].

To this end, the researcher suggests environmental education as a panacea to dearth of environmental issues in our national newspapers, lack of awareness on environmental laws, ensure compliance to these laws and enshrine environmental friendly attitudes.

\subsection{Theoretical Anchor}

This study is anchored on social responsibility theory. This theory places emphasis on the moral and social responsibility of persons and institutions which operate the mass media. It owes its origin to Hutchins Commission on the freedom of the press set up in the United States of America in 1947 to re-examine the concept of press freedom as enunciated in the libertarian theory of the press. The thrust of the social responsibility theory is that socially responsible press should fulfill certain obligations to the society such as: 
A. Provide the people with information and discussion on important social issues and the avoidance of the activities harmful to the public welfare and security of the state.

B. That through professional standard of in formativeness, truth, accuracy, objectivity and balance, these obligations can be met.

C. That the media should regulate itself within the frame work of the law and established institutions to be able to carry out its responsibilities.

D. That based on the principle, the society has the right to expect high standard of performance from the media.

E. That the media should reflect its society's plurality giving access to various points of views and grant all the right to reply.

Following the tenets of this, the press (in this case the Nigerian press) is to provide adequate and unbiased coverage to the issues of environmental pollution in the Niger Delta in furtherance of the region's environmental sustainability for the good of the Nigerian society.

\section{Methodology}

This study adopted the content analysis method in examining the manifest content of four national dailies: The Guardian, Sun, Vanguard and Thisday newspapers with a view to finding out the coverage of environmental pollution in the Niger Delta by the Nigerian press. This design is considered appropriate for this study because of its reliability in analyzing relevant media content as well as giving accurate and dependable results.

The selection of these three newspapers which was done purposively was based on their high circulation and widely diffused market as well as their coverage of all major interest groups in the country.

All the editions of the four newspapers within the period under study constituted the population of study. To this end, a total of 1092 editions constituted the population of study. Out of this population, a total number of 360 editions were content-analyzed.

While purposive sampling was used in selecting the three newspapers content analyzed in this study, systematic random sampling was used in selecting the issues or editions studied. The technique employed here picked editions at $3^{\text {rd }}$ intervals using 4 as my random starting point. Each of the newspapers has 273 editions within the period under study which brings the total editions to 1092. Out of 1092 editions, 90 editions each from the 4 newspapers were drawn out within the nine months study period. Thus, a total of 360 editions representing $32.96 \%$ of the total editions (1092 editions) were analyzed.

The manifest contents analyzed are news stories, features, opinion articles, editorials and letters - tothe- editor. This manifest content refers to the directly visible, objectively identifiable characteristics of a given communication (Okoro 2001: 29) [28].

The following content categories were considered in the study during coding:

(a) Nature of story: It considers whether the news published by these newspapers within the period under study was categorized as news, features, editorial, pictures and cartoons.

(b) Frequency of coverage: This has to do with the number of times the newspapers under study covered stories or issues concerning environmental pollution in the Niger Delta.

(c) Placement: This is the placement of the story in the newspapers under study whether the story is placed in front page, inside page or back page. Placement of story determines their visibility and therefore determines whether they are read by the publics or not.

\section{Findings}

\subsection{Research Question 1: Does Nigerian Press cover environmental pollution in the Niger} Delta.

Table 4: Coverage of environmental pollution by the Nigerian press.

\begin{tabular}{|l|c|}
\hline Newspaper & $\begin{array}{c}\text { Editions with stories on environmental pollution in the } \\
\text { Niger Delta }\end{array}$ \\
\hline Guardian & $2(11 \%)$ \\
\hline Vanguard & $8(44 \%)$ \\
\hline Sun & $3(17 \%)$ \\
\hline Thisday & $5(28 \%)$ \\
\hline Total & $18(100 \%)$ \\
\hline
\end{tabular}

Source: Content analysis 2012

From the table above, it could be seen that Nigerian press cover environmental pollution issues in the Niger Delta. A total of 18 editions of the newspapers studied carried stories on the subject matter out of which Guardian had 2 or $11 \%$, Vanguard had 8 or $44 \%$ as the highest editions with stories on the subject matter, Sun 
Press Coverage Of Environmental Pollution In The Niger Delta Region Of Nigeria. A Content had 3 or $17 \%$ while Thisday had 5 or $28 \%$. This indicates that Nigerian press covers environmental pollution in the Niger Delta.

\subsection{Research Question 2: What is the extent of coverage given to environmental pollution in} the Niger Delta by the Nigerian Press?

On the question of extent of coverage given to environmental pollution in the Niger Delta, the 334 editions of the 4 national newspapers studied carried only 25 stories on the issue under study. Out of these 25 stories, Guardian reported 3 or 12\%, Vanguard had 12 or $48 \%$, Sun carried 5 or $20 \%$ stories on the issue under study and Thisday had 20\% stories on environmental pollution in the Niger Delta. This distribution pattern is presented on a table below.

Table 5: Extent of coverage given to environmental pollution in the Niger Delta by the Nigerian Press.

\begin{tabular}{|c|c|c|}
\hline Newspaper & Frequency & Percentages \\
\hline Guardian & 3 & 12 \\
\hline Vanguard & 12 & 48 \\
\hline Sun & 5 & 20 \\
\hline Thisday & 5 & 20 \\
\hline Total & 25 & 100 \\
\hline
\end{tabular}

Source: Content analysis 2012

This exploratory study came up with quite some interesting revelations on the quantity of coverage given to environmental pollutions in the Niger Delta. Firstly, it discovered that in spite of the growing rate of global concern for the environment, Nigerian newspapers are yet to give adequate coverage to environmental pollution in the Niger Delta region. Secondly, it reveals that media treat the issue of environmental pollution with levity.

10.3 Research Question 3: What is the status of environmental pollution projection in the Nigerian Press?

Table 6: Nature of Story.

\begin{tabular}{|l|c|c|c|c|c|}
\hline \multirow{2}{*}{ Interpretation variable } & \multicolumn{4}{|c|}{ Newspaper } & \multirow{2}{*}{ Total } \\
\cline { 2 - 5 } & Guardian & Vanguard & Sun & Thisday & $14(56 \%)$ \\
\hline Straight News & $3(21 \%)$ & $5(36 \%)$ & $3(21 \%)$ & $3(21 \%)$ & - \\
\hline Editorial & - & - & - & - & $6(24 \%)$ \\
\hline Feature stories & - & $3(50 \%)$ & $2(33 \%)$ & $1(17 \%)$ & $1(4 \%)$ \\
\hline Letters to the editor & - & - & - & 1 & - \\
\hline Cartoon & - & - & & $4(16 \%)$ \\
\hline Supplements & 4 & & & $25(100 \%)$ \\
\hline Total & \multicolumn{7}{|l|}{} \\
\hline
\end{tabular}

Source: Content analysis 2012

On question of the nature of stories published by the newspapers studied, it was found out that the stories were mostly straight news stories or "dead-pan" reports. For example, 14 or $56 \%$ of the stories were straight news stories, 6 or $24 \%$ of the stories were feature stories while 4 or $16 \%$ were supplements while a story was a letter to the editor on the subject matter. From the above table also, it could be seen that vanguard news tops the list in terms of straight news reports, features and supplement on the subject matter.

Also, the table indicates that Daily Sun had 3 or $21 \%$ and 2 or $33 \%$ as straight news and features respectively, Guardian 3 or $21 \%$ as its straight news and had no feature or supplement on the subject matter while Thisday had 3 or $21 \%$ as straight news and 1 or $17 \%$ as feature. Above is an indication of low interpretation given to environmental pollution in the Niger Delta by the Nigerian Press.

On the question of placement of stories on the pages of the newspapers studied, the study showed that all environmental pollution stories in the Niger Delta as covered by the 4 newspapers studied were placed on their inside pages. Guardian recorded 3 or $12 \%$ of the 20 environmental pollution stories in the Niger Delta, Vanguard had 12 or $48 \%$ of the stories on the subject matter on the inside pages, Daily Sun and Thisday had 5 or $20 \%$ all on their stories on the inside pages respectively. None of these stories made the front or the back pages of the newspapers studied

Above indicates poor placement of stories on the environmental pollution in the Niger Delta as none of them were strategically placed on the front or the back pages of the newspapers studied. Story placement shows the importance attached to stories and determine their visibility vis-à-vis their readability. See the table below 
Press Coverage Of Environmental Pollution In The Niger Delta Region Of Nigeria. A Content Table 7: Placement of stories on environmental pollution in the Niger Delta on the pages of the 4 newspapers.

\begin{tabular}{|l|c|c|c|c|c|}
\hline \multirow{2}{*}{ Placement Category } & \multicolumn{4}{|c|}{ Newspaper } & \multirow{2}{*}{ Total } \\
\cline { 2 - 5 } & Guardian & Vanguard & Sun & Thisday & - \\
\hline Front page & - & - & - & - & \\
\hline Inside page & $3(12 \%)$ & $12(48 \%)$ & $5(20 \%)$ & $5(20 \%)$ & $25(100 \%)$ \\
\hline Back Page & - & - & - & & - \\
\hline
\end{tabular}

Source: Content analysis 2012

\subsection{Research Question 4: What are the prevalent of environmental pollution forms in the Niger Delta as reflected by the Nigerian press?}

On the question of types of environmental pollution prevalent in the Niger Delta as covered by the Newspapers studied: Guardian, Vanguard, Daily Sun and Thisday published stories mostly on oil spillage. For instance out of 25 stories on the subject matter 24 or $96 \%$ of the stories were on oil spillage while only 1 of $4 \%$ of the stories published was on gas flaring. There was not even a single story on improper waste disposal and artisanal refining. Also other forms of environmental pollution such as noise pollution had no place in the newspapers. This is an indication that the root cause of environmental pollution in the Niger Delta is oil spillage whether as a result of well blow out, rupture or sabotage. See the table below

Table 8: Prevalent environmental pollution formsin the Niger Delta as reflected by the Nigerian Press.

\begin{tabular}{|l|c|c|c|c|c|}
\hline \multirow{2}{*}{ Variables } & \multicolumn{3}{|c|}{ Newspaper } & \multirow{2}{*}{ Thisday } & \multirow{2}{*}{ Total } \\
\cline { 2 - 5 } & Guardian & Vanguard & Sun & & \\
\hline Oil spillage & $3(12 \%)$ & $11(46 \%)$ & $5(21 \%)$ & $5(21 \%)$ & $24(96 \%)$ \\
\hline Improper waste disposal & - & - & - & - & - \\
\hline Gas flaring & - & 1 & - & & $1(4 \%)$ \\
\hline Artisanal refining & - & - & - & - & - \\
\hline Noise & - & - & - & - & - \\
\hline Total & \multicolumn{7}{|l|}{} & & - & $25(100 \%)$ \\
\hline
\end{tabular}

Source: Content analysis 2012

This study revealed among other things that the press in Nigeria reports environmental pollution in the Niger Delta as shown in the table 5. Though, not much coverage is given to the subject matter.

On the issue of frequency of reportage given on environmental pollution in the Niger Delta, it was discovered that in spite of the growing rate of global concern for the environment, Nigerian press are yet to give adequate coverage to environmental pollution in the Niger Delta region. Again, the study revealed a wide margin among the 4 newspaper studied in their reportage on the subject matter. While Vanguard recorded 12 or 48\% stories in 9 months, it will take Guardian 36 months, Sun and Thisday and 27 months each to achieve Vanguard's height going by their present rate of reportage on environmental pollution in the Niger Delta. This is an indication that some media organizations treat the issue of environmental pollution with levity.

The study also revealed low interpretation given to the subject matter by the 4 newspapers studied as indicated by table 6. Among the 4 newspapers studied: Guardian, Vanguard and Daily Sun, had no editorial on the subject matter during the study period. While Vanguard through its feature stories and supplements gave more interpretation on the subject matter, Guardian had no editorial, feature or supplements on the subject matter. Thisday had 1 editorial and 1 letter to the editor. Therefore, more interpretation should be given to environmental pollution in the Niger Delta since such would aid better understanding and appreciation of the situation on ground. This is because interpreted stories have subtle persuasive content which would help change negative attitudes of Nigerians and corporate bodies towards the environment.

Furthermore, the study revealed poor placement of stories on the environment pollution in the Niger Delta as none of the stories was strategically placed on the front or back pages of the newspapers studied. Since placement of stories determine their visibility and therefore determine whether they are read by readers or not, the press should consider playing up stories on the subject matter through strategic placement bearing in mined that placement given to stories by the media shows the importance attached to these stories. Hence, the press in Nigeria should attach more importance to issues on environmental pollution in the Niger Delta.

Finally, on the aspect of environmental pollution covered by the newspapers studied it showed that oil spillage is the root cause of the environmental pollution in the Niger Delta region. There was no story on artisanal refining, improper waste disposal and noise pollution while gas flaring got only 1 story from the 
Press Coverage Of Environmental Pollution In The Niger Delta Region Of Nigeria. A Content

editions studied. From the study, it could be deduced that noise has not been seen or recognized as a form of environmental pollution in this part of the country even when its implications are enormous.

It was also discovered that out of these 360 editions 334 or $92.7 \%$ of the editions were coded while 26 or $7.2 \%$ of the editions were missing. These missing editions could not be found in the Nnamdi Azikiwe Library, UNN and Enugu State Library, Enugu which were used in the course of this study.

Out of the 26 or $7.2 \%$ of the missing editions, Guardian had 1 edition missing; Vanguard had 2 or $8 \%$ of the editions missing, Daily Sun had 3 or $12 \%$ editions missing while Thisday had 20 or $76 \%$ of the editions missing. Also, out of the 334 editions coded only 18 or $5 \%$ of the editions had stories on environmental pollution in the Niger Delta. Out of which Guardian had 2 or $11 \%$ of its editions with stories, Vanguard had 8 or $44 \%$, Daily Sun had 3 or $17 \%$ editions with stories while Thisday had 5 or $28 \%$ editions with stories.

As regards the 316 or $87.8 \%$ of the editions without stories on environmental pollution in the Niger Delta, Guardian had 87 or $28.7 \%$ of editions without stories; Vanguard had 80 or 25\%, Daily Sun had 84 or $27 \%$ of editions without stories while Thisday had 65 or $20 \%$ of editions without stories on environmental pollution in the Niger Delta.

Above is an indication that Guardian had the lowest number of missing editions, editions with stories on the subject matter and the highest number of editions without stories on the subject matter as well, Thisday had the highest number of missing editions while Vanguard had the highest number of editions with stories on environmental pollution in the Niger Delta. See the table below.

Table 9: Sample distribution of news papers studied

\begin{tabular}{|l|c|c|c|c|c|}
\hline \multirow{2}{*}{ Variables } & \multicolumn{3}{c|}{ Newspapers } & \multirow{2}{*}{ Total } \\
\cline { 2 - 5 } & Guardian & Vanguard & Sun & Thisday & \\
\hline Missing editions & $1(4 \%)$ & $2(8 \%)$ & $3(12 \%)$ & $20(76 \%)$ & $26(7.2 \%)$ \\
\hline $\begin{array}{l}\text { Editions with stories on } \\
\text { environmental pollution in the } \\
\text { Niger Delta }\end{array}$ & $2(11 \%)$ & $8(44 \%)$ & $3(17 \%)$ & $5(28 \%)$ & $18(5 \%)$ \\
\hline $\begin{array}{l}\text { Editions without stories on } \\
\text { environmental pollution in the } \\
\text { Niger Delta }\end{array}$ & $87(28 \%)$ & $80(25 \%)$ & $84(27 \%)$ & $65(20 \%)$ & $316(87.8 \%)$ \\
\hline Total number of editions & 90 & 90 & 90 & 90 & 360 \\
\hline
\end{tabular}

Source: Content analysis 2012

\section{Summary}

Niger Delta region in Nigeria is a region known for oil exploration and related activities. It is a region faced with environmental pollution; one of the threatening environmental problems in Nigeria. Prevalent in this area is oil pollution resulting from oil spills which have caused devastation effects on communities around the area of spill, destroyed aquatic lives, vegetations and farm lands.

This exploratory study which looked at press coverage of environmental pollution in the Niger Delta: a content analysis of 4 national newspapers; The Guardian, Vanguard, Daily Sun and Thisday revealed that Nigerian press covers environmental pollution in the Niger Delta, though the subject matter did not receive much coverage. Also, the study indicated that interpretations given on environmental pollution in the Niger Delta is low expect for Vanguard newspaper that provided little interpretation through its Tuesday edition supplements.

Furthermore, it was discovered that all the stories on environmental pollution the Niger Delta were hidden in the inside pages of the 4 newspapers studied. Not even a single story made the front or the back pages of the newspapers studied. It was also discovered that Vanguard newspaper had the highest number of publication on the subject matter within the 9 months study period while Guardian newspaper had the lowest number of stories on the subject matter.

Finally, the study revealed that root cause of environmental pollution in the Niger Delta is oil spillage even as the researcher tends to believe that environmental education will add impetus to the struggle for having a healthy environment as well as sustainable environment.

\section{Conclusion}

Niger Delta region is an endangered area; threatened by environmental pollution caused by oil exploration and related activities whose remediation cost run into billions of naira and would run for over 30 years. Therefore, further pollution should be vehemently fought and resisted in order not to reap today and compromise the needs of the future generations. Since nature sustains its inhabitants and the fate of nature depends in human hands, there is the need for environmental education to entrench environmental friendly 
Press Coverage Of Environmental Pollution In The Niger Delta Region Of Nigeria. A Content attitudes, better understanding of existing regulations on the environment as well as making of better regulations capable of ensuring a healthy environment that meet human needs and support healthy living.

\section{Recommendations}

For effective coverage of environmental pollution issues in Nigeria, the following steps should religiously be followed by the press:

* Media organizations in the country should assign reporters to cover environmental issues in the country on a regular basis especially in the endangered Niger Delta region. Since issues are seen as important based on media attachments to such issues, emphasis should be placed on environmental pollution in the Niger Delta through frequency of reportage and interpretations.

* Environmental education should be part of the school curriculum from primary to tertiary institutions to inculcate in the people environmental friendly attitudes. Such environmental education should equally be carried out through the traditional media so as to carry along both the literate and illiterate ones in the quest for a healthy environment.

* Oil industries operating in the region should ensure regular maintenance of their equipment to avoid equipment failure and ruptures capable of spewing thousands of barrels of oil unto the land and under ground waters. In case of oil spill, immediate clean up of the environment should be carried out while processes of remediation should commence without delay.

* Inhabitants of the region should avoid illegal activities such as bunkering and artisanal refining which are major causes of environmental pollution in the area. Also, they should avoid sabotaging oil facilities in the area bearing in mind that in case of oil spill it is them that suffers the consequences. Dialogue with oil industries operating in the area should be their watchword in case of threatening situations.

* Government should ensure strict compliance to existing environmental laws and regulations by operators in the oil industry. Also, regulatory agencies such as Department of Petroleum Resources (DPR), National Oil Spill Detection and Response Agency (NOSDRA), Federal Environmental Protection Agency (FEPA) should be alive to their responsibilities.

\section{Journal Papers}

\section{References}

[1] C. A Ashong, and A .J. Udoudo, Media coverage of environmental pollution as a factor in agricultural development in the Niger Delta in the International Journal of Communication 6, May 2007 pp 193 - 204

[2] A Adeyanju,. Government and the oil pollution crisis in Nigeria. In International Journal of Environmental Issues 2( 1 \& 2), 2004. pp $217-227$.

[3] V. Ikuomola, (2011, Aug. 5). N150b needed to clean up Ogoniland. The Nation p.8

[4] S. Ekpo Environmental impacts of petroleum exploration and exploitation in Nigeria. In International Journal of Environmental Issues 7(1) 2010, pp $162-175$

[5] A.T. Busari Public awareness on environmental issues: A Panacea for sustainable environment development in International Journal of Environmental Issues vol. 3 No. 12005

[6] C. E. AkporidoEnvironmental information needs of rural dwellers in oil production communities in Delta State, Nigeria. In International Journal of Environmental Issues 3( 2), pp 18 - 25, 2005

[7] B. O. Odufuwa, Mitigating environmental tragedies in Nigeria. In International Journal of Environmental Issues (3 ( 1)2005, pp $227-239$.

Theses

[8] Ajaero, Chris (2011, Sept. 12) Shell's guilty as charged. Newswatch p. 20

[9] M. N. Akpa Newspaper coverage of urban waste and environmental sanitation in Nigeria: a content analysis of four national daily newspapers, 1995 unpublished thesis, Enugu State University of Science and Technology.

[10] N .C. Anokwute, Newspaper coverage of environmental pollution in Nigeria: A content analysis of 4 Nigerian Newspapers 1999, M. Sc. Research project, Public Relations programme, Department of Marketing, University of Nigeria Enugu Campus.

\section{Internet}

[11] UNEP (2011). Environmental assessment of Ogniland. http: // post conflict. unep.ch //publications/ OEA/UNEP . OEA. pdf retrieved 5/10/2011.

Books

[12] E . Nwosu and V. O. Uffoh, Environmental Public Relations management, (Enugu: IDS University of Nigeria Enugu Campus2005).

[13] Onyilo, M. A. An assessment of press reports on environmental issues in Nigeria in IkeS. Ndolo (ed) Contemporary Issues in Communication and society, (Enugu: Rhyce Kerex Publishers 2011).

[14] N. Okoro Mass communication research, issues and methodologies.(Nsukka: AP Express Publishers 2001).

Papers

[15] Nwosu, I. E. (1997). Media images of environmental issues and problems in Nigeria:implementations for Public Relations managers. A paper presented at the NIPR conference Presidential Hotel. Port-Harcourt, 26 Nov. 